\title{
ANALISIS FAKTOR FAKTOR YANG MEMPENGARUHI PRODUKSI TELUR PUYUH DI GAMPONG GEUNTENG KECAMATAN MEURAH DUA KABUPATEN PIDIE JAYA
}

\author{
ANALYSIS OF FACTORS AFFECTING QUICK EGGS PRODUCTION IN \\ GAMPONG GEUNTENG, MEURAH DUA DISTRICT, PIDIE JAYA REGENCY
}

\author{
Safrika*, Hamdani \\ Program Studi Agribisnis Fakultas Pertanian Universitas Jabal Ghafur \\ Jalan Garot - Lamlo Gle Gapui Kabupaten Pidie \\ *E-mail: safrikarika25@gmail.com \\ (Diterima 05-07-2021; Disetujui 22-07-2021)
}

\begin{abstract}
ABSTRAK
Puyuh merupakan salah satu jenis unggas yang memiliki potensi untuk dikembangkan dan ditingkatkan produksinya. Banyaknya permintaan pasar pada saat ini, memberikan kesempatan bagi peternak telur puyuh di Gampong Geunteng Kecamatan Meurah Dua Kabupaten Pidie Jaya untuk meningkatkan produksi telur puyuh. Kurangnya produksi menjadi masalah bagi peternak karena berdampak terhadap kurangnya upaya untuk memenuhi permintaan pasar. Penelitian ini bertujuan untuk mengetahui faktor-faktor yang mempengaruhi produksi telur puyuh di Gampong Geunteng Kecamatan Meurah Dua Kabupaten Pidie Jaya. Desain penelitian yang digunakan adalah kuantitatif dan kualitatif. Penelitian ini menggunakan metode analisis regresi linear berganda. Hasil penelitian menunjukkan bahwa Penerimaan usaha telur puyuh di Gampong Geunteng Kecamatan Meurah Dua Kabupaten Pidie Jaya sebesar Rp351.920.000 per periode usaha. Berdasarkan hasil dari analisis data menunjukkan bahwa Jumlah pakan dan tenaga kerja berpengaruh terhadap produksi telur puyuh.
\end{abstract}

Kata Kunci: Pendapatan, Faktor Produksi

\section{ABSTRACT}

Quail is one type of poultry that has the potential to be developed and increased production. The high market demand at this time provides an opportunity for quail egg farmers in Gampong Geunteng, Meurah Dua District, Pidie Jaya Regency to increase quail egg production. Lack of production is a problem for farmers because it has an impact on the lack of efforts to meet market demand. This study aims to determine the factors that influence the production of quail eggs in Geunteng Village, Meurah Dua District, Pidie Jaya Regency. The research design used is quantitative and qualitative. This research uses multiple linear regression analysis method. The results showed that the revenue of the quail egg business in Gampong Geunteng, Meurah Dua District, Pidie Jaya Regency was Rp. 351,920,000 per business period. Based on the results of data analysis shows that the amount of feed and labor affect the production of quail eggs.

Keywords: Income, Factors of Production

\section{PENDAHULUAN}

Peternakan merupakan bagian dari pembangunan pertanian yang memiliki peranan yang penting dalam kegiatan ekonomi Indonesia. Tujuan dari pembangunan peternakan adalah untuk memenuhi kebutuhan gizi masyarakat yang bersumber dari protein hewani 
berupa daging, telur, dan susu yang sangat diperlukan untuk meningkatkan kualitas sumberdaya manusia (Kamiluddin, 2012).

Puyuh merupakan salah satu jenis unggas yang memiliki potensi untuk dikembangkan dan ditingkatkan produksinya. Selain menghasilkan daging, puyuh juga menghasilkan telur untuk memenuhi kebutuhan protein hewani bagi masyarakat. Kegiatan usaha peternakan puyuh umumnya masih peternakan rakyat, belum skala industri. Pemeliharaannya belum intensif dibandingkan dengan peternakan ayam ras, namun peternakan puyuh menjadi salah satu kegiatan usaha alternatif yang cukup potensial (Anugrah dkk., 2012).

Pemeliharaan puyuh petelur dibedakan menjadi tiga fase, yaitu fase starter (0-3 minggu), grower (4-6 minggu dengan kebutuhan PK 21-23\%) dan layer (7-60 minggu dengan kebutuhan PK 1820\%) (Abidin, 2005). Temperatur yang nyaman bagi puyuh berkisar $20-25{ }^{\circ} \mathrm{C}$ (Listiyowati dan Kinanti, 2009). Kelembaban kandang idealnya berkisar $30-80 \%$. Kandang yang memiliki kelembaban tinggi memicu perkembangan mikroorganisme dan bakteri, sehingga menimbulkan penyakit bagi puyuh (Tetty, 2011).
Banyaknya permintaan pasar pada saat ini, memberikan kesempatan bagi peternak telur puyuh di Gampong Geunteng Kecamatan Meurah Dua Kabupaten Pidie Jaya untuk meningkatkan produksi telur puyuh. Kurangnya produksi menjadi masalah bagi peternak karena berdampak terhadap kurangnya upaya untuk memenuhi permintaan pasar.

Beberapa faktor yang mempengaruhi produksi adalah pakan dan tenaga kerja. Pakan adalah salah satu faktor yang sangat penting untuk mencapai produktivitas burung puyuh secara optimal, oleh karena itu kuantitas dan kualitas pakan hendaknya selalu diperhatikan. Biaya pakan merupakan komponen biaya terbesar yang mencapai $60-70 \%$ dari total biaya produksi ternak unggas (Anggitasari, Sjofjan, dan Djunaidi, 2016).

Pakan komersial adalah pakan jadi buatan pabrik yang telah diedarkan ke masyarakat. Pakan komersial telah menjadi pakan ternak yang paling banyak digunakan oleh peternak. Keunggulan dari pakan komersial ini adalah praktis karena peternak tidak perlu meransum pakan sendiri dan pakan komersial selalu tersedia di pasar. Sedangkan faktor tenaga kerja menunjukkan kemampuan 
manusiawi yang dapat disumbangkan untuk memungkinkan dilakukannya proses produksi.

Berdasarkan uraian latar belakang di atas penulis tertarik untuk melakukan penelitian dengan judul "Analisis faktorfaktor yang mempengaruhi produksi telur puyuh di Gampong Geunteng Kecamatan Meurah Dua Kabupaten Pidie Jaya”.

\section{METODE PENELITIAN}

Penelitian ini dilakukan di Gampong Geunteng Kecamatan Meurah Dua Kabupaten Pidie Jaya. Lokasi ditentukan secara sengaja (purposive) karena merupakan salah satu tempat produksi telur puyuh di Kecamatan Meurah Dua Kabupaten Pidie Jaya. Untuk memperoleh data yang akurat penelitian ini menggunakan dua macam pengumpulan data, yaitu data primer dan sekunder.

Batasan variabel yang digunakan dalam penelitian ini adalah jumlah pakan dan biaya tenaga kerja yang akan dianalisis untuk memperhitungkan faktor yang mempengaruhi produksi telur puyuh. Jumlah pakan (X1) merupakan seluruh pakan yang diberikan selama periode pengamatan, satuan dalam $\mathrm{kg}$. Biaya tenaga kerja (X2) merupakan besarnya pengeluaran untuk membayar sejumlah orang kerja, satuan dalam Rp. Produksi telur puyuh (Y), yaitu jumlah telur puyuh yang dihasilkan selama pengamatan, satuan dalam butir.

Perhitungan besaran pendapatan usaha telur puyuh dalam penelitian ini dihitung dengan menggunakan rumus keuntungan:

$$
\pi=\text { TR-TC }
$$

dimana:

$\pi$ : Pendapatan usaha (Rp/periode usaha)

TR: Penerimaan (Rp/periode usaha)

TC: Biaya produksi (Rp/periode usaha)

Analisa faktor produksi dalam penelitian ini menggunakan analisis regresi linear berganda dengan model analisis adalah:

$$
Y=a+b_{1} X_{1}+b_{2} X_{2}+e
$$

Dimana:

$a=$ Konstanta

$b_{1}=$ Koefisien regresi variabel produk

$b_{2}=$ Koefisien regresi variabel harga

$\mathrm{Y}=$ Produksi telur

$X_{1}=$ Jumlah pakan

$X_{2}=$ Biaya tenaga kerja

$\mathrm{e}=$ error (variabel bebas lain diluar model regresi)

\section{HASIL DAN PEMBAHASAN}

Penelitian ini dilakukan pada usaha budidaya telur puyuh yang berada di Gampong Geunteng Kecamatan Meurah 
Dua Kabupaten Pidie Jaya. Usaha ini pertama kali didirikan pada tahun 2013 oleh Fadlan, dengan modal pertama sebesar tiga puluh lima juta rupiah. Hal yang melatarbelakangi pilihan usahanya berkaitan dengan peluang usaha budidaya telur puyuh. Berbekal informasi budidaya telur puyuh yang diperolehnya dari media online, Fadlan memutuskan untuk mengelola usaha budidaya telur puyuh. Pada tahap awal dibudidayakan sekitar 2.000 ekor puyuh siap bertelur. Saat ini, usaha budidaya telur puyuhnya sudah mulai berkembang baik dari segi volume produksi maupun wilayah pemasarannya.

Usaha budidaya telur puyuh dikelola langsung oleh Fadlan dibantu oleh karyawan tetap sebanyak 1 orang. Namun, jika pekerjaan perlu tambahan tenaga kerja maka biasanya disewa dengan sistem pembayaran harian. Menurut Fadlan, usaha ini merupakan usaha sampingan yang sangat prospektif karena selain sebagai peternak telur puyuh, ia juga bermata pencaharian sebagai tukang bangunan.

Sebelum membahas biaya produksi pada budidaya telur puyuh ada beberapa asumsi sebagai berikut:

1. Bibit telur puyuh berumur 30 hari sewaktu dibeli.
2. Burung puyuh mulai bertelur pada umur 40 hari dan efektivitas bertelur hingga 18 bulan (periode usaha 540 hari dan periode bertelur sekitar 530 hari).

Biaya produksi pada usaha budidaya telur puyuh yaitu sebesar Rp247.410.000/periode usaha. Biaya ini terdiri atas biaya bibit sebesar Rp14.000.000, pakan sebesar Rp154.440.000, vitamin sebesar Rp250.000, tenaga kerja sebesar Rp75.600.000, dan penyusutan sebesar Rp3.120.000/periode usaha. Berdasarkan persentase biaya dapat dilihat bahwa biaya pakan merupakan tertinggi yaitu sebesar $62,42 \%$ kemudian biaya tenaga kerja yaitu sebesar 30,56\%.

Penerimaan adalah rata-rata produksi dikali harga pasar yang diterima peternak. Tujuan akhir dari suatu usaha adalah untuk memperoleh pendapatan. Pendapatan usaha merupakan selisih antara penerimaan dan biaya produksi. Pendapatan menunjukkan tingkat profitabilitas yang diperoleh peternak selama menjalankan usahanya dalam satu periode usaha. Semakin tinggi selisih penerimaan-biaya, maka usaha tersebut semakin menguntungkan (Suratiyah, 2012). Data produksi, penerimaan, dan pendapatan usaha budidaya telur puyuh 
di lokasi penelitian dapat dilihat pada tabel berikut.

Tabel 1. Pendapatan Budidaya Telur puyuh per Periode Usaha di Gampong Geunteng Kecamatan Meurah Dua Kabupaten Pidie Jaya Tahun 2020

\begin{tabular}{llr}
\hline \multicolumn{1}{c}{ Uraian } & Satuan & \multicolumn{1}{c}{ Jumlah } \\
\hline A. Produksi & Butir & 879.800 \\
B. Harga & Rp/butir & 400 \\
C. Penerimaan (AxB) & Rp/periode & 351.920 .000 \\
D. Biaya Produksi & Rp/periode & 247.410 .000 \\
E. Pendapatan (A-B) & Rp/periode & 104.510 .000 \\
\hline
\end{tabular}

Berdasarkan Tabel 2 dapat dijelaskan bahwa rata-rata produksi telur puyuh sebesar $83 \%$ per hari atau produksi selama periode usaha sebanyak $83 \% \mathrm{x}$ $2000 \times 530$ hari $=879.800$ butir. Harga telur puyuh diambil rata-rata sebesar Rp400/butir. Dengan demikian, penerimaan yang diperoleh peternak yaitu sebesar: 879.800 butir x Rp400 = Rp351.920.000 per periode usaha. Pendapatan usaha telur puyuh sebesar $\operatorname{Rp} 351.920 .000-\operatorname{Rp} 247.410 .000=$ Rp104.510.000 per periode usaha.

Berdasarkan hasil analisis data biaya produksi diketahui bahwa biaya pakan dan tenaga kerja merupkan komponen biaya terbesar dalam usaha budidaya telur puyuh di Gampong Geunteng Kecamatan Meurah Dua Kabupaten Pidie Jaya. Untuk mengetahui seberapa besar pengaruh perubahan biaya pakan dan tenaga kerja terhadap produksi telur puyuh dilakukan melalui analisis regresi linear berganda. Hasil analisis data dengan menggunakan software SPSS versi 21.0 ditampilkan pada tabel berikut:

Tabel 2. Pengaruh Variabel Independen terhadap

\begin{tabular}{lcccc}
\multicolumn{5}{c}{ Variabel Dependen } \\
\hline \multicolumn{1}{c}{ Nama Variabel } & $\mathrm{B}$ & $\mathrm{t}_{\text {hitung }}$ & $\mathrm{t}_{\text {tabel }}$ & Sign \\
\hline (Constant) & .291 & 1.622 & & .113 \\
Pakan & .025 & 5.145 & 2.026 & .000 \\
Tenaga_Kerja & .002 & 4.769 & 2.026 & .000 \\
Koefisien Korelasi & .903 & & & \\
(R) & & & & \\
Koefisien & .815 & & & \\
Determinasi & & & & \\
(R ${ }^{2}$ ) & & & & \\
Adjusted R Squares & .805 & & & \\
$\mathrm{~F}_{\text {hitung }}$ & 81.632 & & \\
$\mathrm{~F}_{\text {tabel }}$ & 3.259 & & \\
Sign F & 0.000 & & \\
\hline
\end{tabular}

Tabel 2 menunjukan hasil analisis data menggunakan program software SPSS versi 21.0 diperoleh model persamaan regresi linear berganda sebagai berikut:

$$
\mathrm{Y}=0.291+0,025 \mathrm{X}_{1}+0.002 \mathrm{X}_{2}
$$

Persamaan regresi linear berganda di atas dapat diinterpretasikan sebagai berikut:

1. Nilai konstanta sebesar 0.291 berarti jika variabel jumlah pakan $\left(\mathrm{X}_{1}\right)$ dan tenaga kerja $\left(\mathrm{X}_{3}\right)$ dianggap konstan, maka produksi telur puyuh adalah 0.291 .

2. Nilai koefisien regresi variabel jumlah pakan sebesar $0.025 \%$ dapat diartikan bahwa setiap $1 \%$ kenaikan variabel jumlah pakan $\left(\mathrm{X}_{1}\right)$ akan 
meningkatkan produksi telur puyuh (Y) sebesar $0.025 \%$. Jika variabel $\mathrm{X}_{2}$ dianggap konstan maka berarti terjadi peningkatan produksi telur puyuh.

3. Nilai koefisien regresi variabel jumlah tenaga kerja sebesar $0.002 \%$ berarti setiap 1\% kenaikan jumlah tenaga kerja $\left(\mathrm{X}_{2}\right)$ akan meningkatkan produksi telur puyuh (Y) sebesar $0.002 \%$. Jika variabel $\mathrm{X}_{1}$ dianggap konstan, berarti terjadi peningkatan produksi telur puyuh.

Berdasarkan hasil analisis di atas dapat disimpulkan bahwa dari kedua variabel yang diteliti, ternyata variabel jumlah pakan $\left(\mathrm{X}_{1}\right)$ mempunyai pengaruh paling dominan terhadap produksi telur puyuh.

Hubungan antara variabel jumlah pakan $\left(\mathrm{X}_{1}\right)$ dan jumlah tenaga kerja $\left(\mathrm{X}_{2}\right)$ terhadap produksi telur puyuh (Y) diperoleh nilai indeks korelasi sebesar $90.3 \%$. Kemudian indeks determinasi masing-masing variabel bebas (X) terhadap variabel terikat $(\mathrm{Y})$ diperoleh sebesar $81.5 \%$ yang berarti bahwa varisi variabel bebas dapat menjelaskan variabel terikat sebesar $81.5 \%$ sedangkan selebihnya yaitu $18.5 \%$ dipengaruhi oleh variabel lain yang tidak diteliti dalam penelitian ini.

\section{KESIMPULAN DAN SARAN}

Penerimaan usaha telur puyuh di Gampong Geunteng Kecamatan Meurah Dua Kabupaten Pidie Jaya sebesar Rp351.920.000 per periode usaha dan biaya produksi sebesar Rp247.410.000 per periode usaha, sehingga diperoleh pendapatan sebesar Rp104.510.000 per periode usaha.

Hasil pengujian secara simultan diperoleh nilai $F_{\text {hitung }} 81.632>F_{\text {tabel }}$ 3.252 , artinya bahwa variabel jumlah pakan $\left(\mathrm{X}_{1}\right)$ dan biaya tenaga kerja $\left(\mathrm{X}_{2}\right)$ secara bersama-sama berpengaruh secara signifikan terhadap produksi telur puyuh di lokasi penelitian. Variabel jumlah pakan $\left(\mathrm{X}_{1}\right)$ dan jumlah tenaga kerja $\left(\mathrm{X}_{2}\right)$ secara parsial berpengaruh signifikan terhadap produksi telur di Gampong Geunteng Kecamatan Meurah Dua Kabupaten Pidie Jaya.

Diharapkan agar pengambil kebijakan di daerah setempat memperhatikan keberlanjutan usaha kecil dan menengah, khususnya usaha budidaya telur puyuh. Agar lebih disosialisasikan konsumsi telur puyuh melalui berbagai acara pentas kuliner. Disarankan pemilik usaha telur puyuh melakukan kerja sama dengan pemilik usaha kuliner seperti rumah makan, pedagang jajanan sehat, dan lain-lain 
untuk menjamin kontiuitas pemasaran sekaligus usahanya.

\section{DAFTAR PUSTAKA}

Anggitasari, S., Sjofjan, O. dan Djunaidi, I. H. 2016. Pengaruh beberapa jenis pakan komersial terhadap kinerja produksi kuantitatif dan kualitatif ayam pedaging. Buletin Peternakan Vol 40 (3) : 187-196.

Tetty. 2011. Puyuh Si Mungil Penuh Potensi. Agro Media Pustaka, Jakarata.
Anugrah, I. S., I. Sadikin dan W. K. Sejati. 2012. Kebijakan kelembagaan usaha unggas tradisional sebagai sumber ekonomi rumah tangga perdesaan: kasus peternakan burung puyuh Yogyakarta. Analisis Kebijakan Pertanian. 7(3): 249-267.

Kamiludin. 2012. Analisis Pendapatan Usaha Peternakan Sapi Perah di Kawasan Peternakan Sapi Perah Cibungbulang Kabupaten Bogor. Skripsi. Fakultas Ekonomi dan Manajemen, Institut Pertanian Bogor. Bogor. 